\title{
Chilean Construction Institute: building consensus in coordinating common issues
}

\author{
Francis Pfenniger ${ }^{1, *}$ \\ ${ }^{1}$ University of Chile, Faculty of Architecture and Urbanism, Avenida Libertador Bernardo O'Higgins \\ 1058, Santiago, Chile
}

\begin{abstract}
The twenty years of research experience of the Chilean Construction Institute (IC) to promote "public and private efforts to improve quality, productivity and sustainability in construction" are presented in this paper. IC is a non-profit organisation formed by some public, private and academic actors: two ministries, two universities (Universidad de Chile and Universidad Católica de Chile) the Chilean Construction Chamber, three guilds (Architects, Builders and Engineers) and private industries (from the materials sector) formed this very atypical organisation back in the nineteen-nineties. The IC is a transverse association in which the actors meet freely to discuss issues that affect the construction sector, trying to find common proposals to contribute regarding the development of the country. Important actions have been developed, such as the Chilean isolation regulation; the social housing pathologies study; the National Construction Norms Council; the Chilean construction norms site; the public buildings case study; the CES - Chilean building certification system; the digitalisation of the building authorization system (on the municipal level); the Regional Seismic Code (for all Latin American and Caribbean countries) and others impossible to include here. This effort has proved to be effective and efficient in order to promote regulation upgrading and conduct studies that would otherwise be difficult to do. An interesting case is the thermal isolation regulation: with the support of the academic world, it was possible to agree a common starting point which, at the beginning, was strongly opposed by some actors. This updated regulation has proven that this public-private and academic joint venture is reliable and effective. Two cases are discussed in detail in this document.
\end{abstract}

\section{Introduction}

It is known that different interests converge and sometimes collide with regard to construction, especially the private, public, academic and professional worlds. The coordination of relationships and actions between these actors are usually mediated by public institutions. State actions are usually concentrated on actors of great impact on the activity (the industry) to the detriment of the actors of less relative weight (the academy, the professional associations and other minor industries). Aware of this scenario, the proposal

*Corresponding author: fpfenniger@uchilefau.cl 
to create an entity that allows the free inclusion concurrence and participation of all actors in the construction sector arises.

The formation of the Chilean Construction Institute is one of the results of the Housing Quality and Industrialization Commission convened by the Ministry of Housing and Urban Planning (MINVU) in 1992 with the aim of seeking strategies to improve social housing standards in Chile. More than 100 professionals representing the entire construction sector met weekly to develop a common diagnosis providing new standards for social housing. new ways. The proposal to create an institutional framework to provide reflection and discussion was one of the committee's proposals.

A working group was established in 1993 comprising: The Ministry of Public Works, the Ministry of Housing and Urban Planning, the Chilean Chamber of Construction, the professional associations of architects, civil engineers and construction engineers, the Universities of Chile and the Catholic University of Chile. A special law which empowers these ministries to be part of the constitution of the private law corporation was published in 1995. The first meeting of the constitution of the IC took place in 1996 and the first ordinary general assembly of members was held in 1997, after a laborious wait of five years. Today, after more than 22 years, the members of the Chilean Construction Institute have increased in quantity and representation (see details at www.iconstrucción.cl) and great work has been done. The institute is, as stated in its Vision, a "meeting place for all relevant actors in the sector - public and private - where long-term country issues proposals are 'generated', with the aim of positively influencing the living conditions of its inhabitants". True to its mission of "Articulating public and private efforts aimed at improving the quality, productivity and sustainability of the construction sector, identifying and prioritising issues, to generate work proposals and lines of action" the institute has developed actions that are relevant for the construction sector in Chile concentrated in three fundamental areas: sustainability, productivity and structure.

In this document, two relevant projects developed by the Chilean Construction Institute will be discussed: the development of proposals for the 2nd stage of thermal regulation and the development of a sustainable building certification system (CES).

\section{Proposal for thermal regulation}

In 1996, also as a result of the Quality and Industrialization Commission, the Ministry of Housing and Urban Development proposed regulation of the thermal conditioning of homes in three phases: a) requirements for the roofing complex, b) requirements for exterior walls, ventilated floors and windows and c) global performance requirements / energy certification [1].

The first stage of this program was directly developed by the Ministry of Housing and Urban Planning in 1993 and was led by the architect José Pedro Campos, who is currently the executive director of the construction institute. According to our NCh1079 [2] Chile has nine climatic zones (with a multifactor approach including temperature, insolation, humidity, winds, rainfall and snowfall, cloudiness and salinity, among others). Heating degree days (HDD) were considered in order to establish seven thermal zones for the purpose of thermal regulation. For this, the base temperature was established at $15^{\circ} \mathrm{C}$ (under the hypothesis that the difference between $15^{\circ} \mathrm{C}$ and the comfort temperature is compensated by clothing and / or the thermal inertia of the building) with data being collected from forty meteorological stations. The national territory was divided with a grid comprised of $200 \times 200 \mathrm{~m}$ squares interpolating the meteorological data adjusted by height in metres above sea level. The study was limited to heating requirements over 50 heating degree day (HDD), given that cooling is not so necessary and is totally absent in social houses. Economic profitability analysis was needed and different criteria were discussed 
and agreed (i.e. prioritising urban areas, taking in account county borders, limiting the different zones inside the county to three, etc.) in order to finally establish seven thermal zones. This thermal zoning is in force until today (although it is currently under review). Finally, in January 2000, the first thermal regulation of Latina America was published in Chilean regulatory documents.

Aware of the urgency and benefits of building insulation, the construction institute proposed to develop the second stage of the thermal regulation, which was accepted by the Ministry of Housing and Urban Development. The basic concept of this offer was to promote the participation of the greatest number of actors and to obtain private financing for the studies. Prof. architect doctor Marcelo Huenchuñir was the technical secretary.

The objectives were to improve the quality of life of the population with regard to better thermal comfort, greater habitability, better health, less indoor pollution and greater durability of the home; optimize and/or reduce energy consumption in the residential sector; promote and stimulate productive, industrial, academic, union and applied research activity. The participation of the actors was provided in three ways: A design committee was set up with wide participation of the industry and the Academy, the task of which was to set the general methodology, the research programs and the budget. In a second phase, more participants joined integrated the design committee, with crucial participation of the cement industry and ceramic brick producers. A committee of co-financers (industries and industrial associations that could benefit from thermal regulation) contributes $100 \%$ of the financing. Their task was also to provide constructive solutions, opportunities and to predict possible difficulties. Finally, a validating process was performed with an open inquiry to members of professional associations of architects, builders and engineers and the Chamber of Construction.

The studies and research were: Typologies: due to climatic and cultural differences it was important to find the most representative characteristics of the houses built over the previous 5-year period (1994-1998 according to latest available statistical information), identifying at least two typologies for each thermal zone. Based on statistical information from the National Statistics Institute (INE) [3] for the period, a total of 659.000 homes were studied and 15 different typologies were found (representing 74\% of the total built).

Table 1. Housing typologies - period 1994-1998 - built park.

\begin{tabular}{|c|l|c|c|c|}
\hline Nbr & \multicolumn{1}{|c|}{ Type } & Houses & \% & Projects \\
\hline 1 & 1 storey <50 sq. m - brick & 91,610 & 13.09 & 23,959 \\
\hline 2 & 2 storeys <50 sq. m - brick & 80,871 & 12.26 & 913 \\
\hline 3 & 1 storey <50 sq. m - timber & 57,675 & 8.75 & 26,143 \\
\hline 4 & 3 storeys <50 sq. m - apartments - brick & 51,177 & 7.76 & 157 \\
\hline 5 & 1 storey 50-100 sq. m - brick & 48,838 & 7.41 & 8,982 \\
\hline 6 & 2 storeys 50-100 sq. m - brick & 37,415 & 5.67 & 1,434 \\
\hline 7 & 2 storeys < 50 sq. m - timber & 22,399 & 3.40 & 1,145 \\
\hline 8 & 2 storeys 50-100 sq. m - brick + timber & 20,250 & 3.07 & 1,815 \\
\hline 9 & $\begin{array}{l}11 \text { to 15 storeys - 50-100 sq. m - apartments - } \\
\text { reinforced concrete }\end{array}$ & 13,997 & 2.12 & 112 \\
\hline 10 & 6 to 10 storeys 50-100 sq. m - reinforced concrete & 13,292 & 2.02 & 254 \\
\hline 11 & 2 storeys <50 sq. m - brick-timber & 12,257 & 1.86 & 264 \\
\hline 12 & 1 storey 50-100 sq. m - timber & 10,883 & 1.65 & 8,599 \\
\hline 13 & $\begin{array}{l}5 \text { storeys 50-100 sq. m - apartments - reinforced } \\
\text { concrete }\end{array}$ & 10,580 & 1.60 & 180 \\
\hline 14 & 3 storeys 50-100 sq. m - brick & 9,024 & 1.37 & 92 \\
\hline 15 & 2 storeys 50-100 sq. m - brick + timber & 7,342 & 1.11 & 1,727 \\
\hline
\end{tabular}




\begin{tabular}{|l|l|c|c|c|}
\hline & Total houses in 15 typologies & 487,610 & $73.94 \%$ & - \\
\hline & Total studied houses from statistics & 659,429 & $100.00 \%$ & - \\
\hline
\end{tabular}

\subsection{Typological models}

These 15 typologies were transformed to representative typological models. For this, plans for each type were random collected from official county information sources and worked out in one single general plan to study thermal standards. High ranges of thermal transmittance of existing homes were found, as is shown in Table 2.

Table 2. Thermal transmittance analysis of housing typologies built in the period 1994-1998.

\begin{tabular}{|c|c|c|c|}
\hline Typology & Description & $\begin{array}{c}\text { Houses } \\
\text { (qty) }\end{array}$ & $\begin{array}{c}\text { Thermal } \\
\text { transmittance average } \\
\text { of vertical elements } \\
\mathbf{W} / \mathbf{m}^{2} \mathbf{K}\end{array}$ \\
\hline 1 & 1 storey $<50$ sq. $\mathrm{m}-$ brick & 91,610 & 2.8 \\
\hline 2 & 2 storeys $<50$ sq. $\mathrm{m}-$ brick & 80,871 & 2.7 \\
\hline 3 & 1 storey $<50$ sq. $\mathrm{m}-$ timber & 57,675 & 2.6 \\
\hline 4 & $\begin{array}{l}3 \text { storeys }<50 \text { sq. m - apartments - } \\
\text { brick }\end{array}$ & 51,177 & 2.9 \\
\hline 5 & 1 storey $50-100$ sq. $\mathrm{m}$ - brick & 48,838 & 2.7 \\
\hline 6 & 2 storeys $50-100$ sq. $\mathrm{m}$ - brick & 37,415 & 2.8 \\
\hline 7 & 2 storeys $<50$ sq. $\mathrm{m}-$ timber & 22,399 & 3.0 \\
\hline 8 & $\begin{array}{l}2 \text { storeys } 50-100 \text { sq. } \mathrm{m} \text { - brick }+ \\
\text { timber }\end{array}$ & 20,250 & 2.3 \\
\hline 9 & $\begin{array}{l}11 \text { to } 15 \text { storeys }-50-100 \text { sq. } \mathrm{m} \text { - } \\
\text { apartments - reinforced concrete }\end{array}$ & 13,997 & 3.9 \\
\hline 10 & $\begin{array}{l}6 \text { to } 10 \text { storeys } 50-100 \text { sq. } \mathrm{m}- \\
\text { reinforced concrete }\end{array}$ & 13,292 & 3.9 \\
\hline 11 & 2 storeys $<50$ sq. $\mathrm{m}$ - brick -timber & 12,257 & 2.9 \\
\hline 12 & 1 storey $50-100$ sq. $\mathrm{m}$ - timber & 10,883 & 2.2 \\
\hline 13 & $\begin{array}{l}5 \text { storeys } 50-100 \text { sq. } \mathrm{m} \text {-apartments - } \\
\text { reinforced concrete }\end{array}$ & 10,580 & 3.7 \\
\hline 14 & 3 storeys $50-100$ sq. $\mathrm{m}$ - brick & 9,024 & 3.1 \\
\hline \multirow[t]{2}{*}{15} & $\begin{array}{l}2 \text { storeys } 50-100 \text { sq. } \mathrm{m}-\text { brick }+ \\
\text { timber }\end{array}$ & 7,342 & 2.7 \\
\hline & Total Houses & 487,610 & \\
\hline
\end{tabular}

\subsection{Studies, simulations, profitability calculations and proposals}

It Three groups of studies were developed by different universities. The following conditions were adopted for the simulations:

- Indoor temperature conditions: $20^{\circ} \mathrm{C}$ from $08: 00$ to $23: 00$ and $17^{\circ} \mathrm{C}$, from 23:00 to 08:00;

- Criteria for the percentage of interior humidity;

- Criteria for calculating the value of energy;

- Variables for profitability calculation: 20 -year term, $7.8 \%$ rate and two models.

The study of Concepción University revealed a high energy demand from thermal zone 3 to the south. 
Table 3. Energy demand $\left[\mathrm{KW}-\mathrm{h} / \mathrm{m}^{2}\right.$ year $]$.

\begin{tabular}{|c|c|c|c|c|c|c|c|c|}
\hline \multirow{2}{*}{ Typology } & \multicolumn{7}{|c|}{ Thermal Zone } \\
\cline { 2 - 9 } & $\mathbf{Z 1}$ & $\mathbf{Z 2}$ & $\mathbf{Z 3}$ & $\mathbf{Z 4}$ & $\mathbf{Z 5}$ & $\mathbf{Z 6}$ & $\mathbf{Z 7}$ & $\mathbf{Z 8}$ \\
\hline T01 & 26 & 80 & 110 & 154 & 169 & 204 & 358 & 157 \\
\hline T02 & 27 & 84 & 116 & 163 & 179 & 216 & 376 & 164 \\
\hline T03 & 17 & 58 & 87 & 118 & 131 & 152 & 277 & 161 \\
\hline T04 & 19 & 66 & 97 & 133 & 151 & 181 & 325 & 125 \\
\hline T05 & 24 & 80 & 111 & 153 & 172 & 206 & 365 & 149 \\
\hline T06 & 24 & 81 & 108 & 152 & 169 & 202 & 349 & 155 \\
\hline T07 & 15 & 46 & 65 & 91 & 100 & 120 & 215 & 101 \\
\hline T08 & 20 & 65 & 93 & 125 & 141 & 168 & 301 & 122 \\
\hline T09 & 14 & 50 & 73 & 101 & 115 & 138 & 253 & 94 \\
\hline T10 & 11 & 40 & 62 & 83 & 97 & 115 & 215 & 74 \\
\hline T11 & 28 & 82 & 111 & 158 & 172 & 208 & 361 & 168 \\
\hline T12 & 42 & 116 & 154 & 226 & 238 & 287 & 494 & 278 \\
\hline T13 & 17 & 62 & 92 & 125 & 143 & 170 & 309 & 113 \\
\hline T14 & 15 & 50 & 74 & 102 & 115 & 138 & 251 & 101 \\
\hline T15 & 20 & 66 & 97 & 133 & 150 & 178 & 323 & 147 \\
\hline
\end{tabular}

Acoustic conditions, lighting and the impact of condensation were included in the analysis. In addition, the design committee received studies developed by interested actors such as:

- "Economic Feasibility Study of Implementing a Thermal Insulation System", (developed on behalf of the Cement Producers Association -APROCEM);

- "Study of thermal behaviour of windows proposed for the 2nd phase of thermal regulation of homes" (developed on behalf of related companies);

- "Calculation of the maximum U to avoid superficial condensation"

- "Report on alternatives to improve the thermal characteristics of ceramic brick" (requested by the construction institute to the association of manufacturers of red ceramics $-\mathrm{AFCR}$ ).

Finally, even though there was consensus regarding the thermal insulation requirements for window and floors, there was no consensus about exterior wall standards. Two subcommittees (academic and industrial) were created as a strategy to approach positions. Given the impossibility of building an agreement, there was no other choice than to prepare two different proposals. In September 2003, the final report was presented to the Ministry of Housing and Urban Development. The next table shows the final proposal.

Table 4. Final thermal regulation proposal.

\begin{tabular}{|c|c|c|c|c|c|c|c|c|c|c|}
\hline \multirow{4}{*}{ Zone } & \multicolumn{4}{|c|}{ Exterior walls } & \multicolumn{4}{|c|}{ Windows } & \multirow{2}{*}{\multicolumn{2}{|c|}{$\begin{array}{l}\text { Ventilated } \\
\text { floors }\end{array}$}} \\
\hline & \multicolumn{2}{|c|}{ Option "A" } & \multicolumn{2}{|c|}{ Option "B" } & \multicolumn{3}{|c|}{$\begin{array}{c}\text { Max. window surface on } \\
\text { exterior walls (\%) }\end{array}$} & \multirow{2}{*}{$\begin{array}{c}\begin{array}{c}\mathbf{U} \\
\text { value }\end{array} \\
\mathbf{U}\end{array}$} & & \\
\hline & $\mathbf{U}$ & $\mathbf{R t}$ & $\mathbf{U}$ & $\mathbf{R t}$ & $\begin{array}{l}\text { Monolít } \\
\text { ic glass }\end{array}$ & double- & lazing & & $\mathbf{U}$ & Rt \\
\hline & $\begin{array}{r}\text { W/ } \\
\mathbf{m}^{2} \mathbf{k}\end{array}$ & $\underset{/ \mathbf{w}}{\mathbf{M}^{2} \mathbf{k}}$ & $\begin{array}{l}\mathbf{W} / \\
\mathbf{m}^{2} \mathbf{k}\end{array}$ & $\underset{/ \mathbf{w}}{\mathbf{M}^{2} \mathbf{k}}$ & & $\begin{array}{c}3.6 \geq \mathrm{u} \\
>2.4 \\
\mathrm{w} / \mathrm{m}^{2} \mathrm{k}\end{array}$ & $\begin{array}{c}\mathrm{U} \leq \\
2.4 \\
\mathrm{w} / \mathrm{m}^{2} \mathrm{k}\end{array}$ & & $\underset{\mathbf{W} / \mathbf{m}}{{ }^{2} \mathbf{k}}$ & $\begin{array}{c}\mathbf{M}^{2} \mathbf{k} \\
/ \mathbf{w}\end{array}$ \\
\hline 1 & 4.3 & 0.23 & 4.0 & 0.25 & 50 & 60 & 80 & 5.80 & 3.60 & 0.28 \\
\hline 2 & 3.1 & 0.33 & 1.8 & 0.56 & 40 & 60 & 80 & 3.80 & 0.87 & 1.15 \\
\hline 3 & 2.1 & 0.48 & 1.5 & 0.67 & 25 & 60 & 80 & 2.80 & 0.70 & 1.43 \\
\hline
\end{tabular}




\begin{tabular}{|l|l|l|l|l|l|l|l|l|l|l|}
\hline $\mathbf{4}$ & 1.9 & 0.53 & 1.3 & 0.77 & 21 & 60 & 80 & 2.48 & 0.60 & 1.67 \\
\hline $\mathbf{5}$ & 1.8 & 0.63 & 1.1 & 0.91 & 18 & 51 & 80 & 2.25 & 0.50 & 2.00 \\
\hline $\mathbf{6}$ & 1.3 & 0.83 & 1.1 & 0.91 & 14 & 37 & 55 & 1.86 & 0.39 & 2.56 \\
\hline $\mathbf{7}$ & 0.8 & 1.25 & 0.6 & 1.67 & 12 & 28 & 37 & 1.33 & 0.32 & 3.12 \\
\hline
\end{tabular}

Option A (less demanding) is supported by some of the members of the design committee (cements and ceramics), the industrials subcommittee, and some of the cofinanciers (manufacturers of ceramics, cements, aluminium). In the sectorial consultation this option received support of the Chilean Chamber of Construction and the Civil Constructors.

Option B (more demanding) is endorsed by part of the design committee (National Energy Commission, Expanded Polystyrene Producers Association, academic members, a gypsum-cardboard manufacturer and a construction company), the academic subcommittee and receives the support of the Professional Associations of Architects and Engineers and from the members of the committee of co-financiers (insulation industry, prefabricated systems, suppliers of dry construction systems).

Without going into the details of the fundamentals and the arguments of each of the options, it is evident that there are clearly opposing interests. The final decision was made by the Ministry of Housing and Urban Planning.

The modification of the General Urbanism and Constructions Regulations was finally published in January 2006 according to the recommendations of the final report. The differences in wall complex regulations were solved according to following requirements:

Table 5. Art. 4.1.10 OGUC - Table 1 [4].

\begin{tabular}{|c|c|c|c|c|c|c|}
\hline \multirow{2}{*}{ Zone } & \multicolumn{2}{|c|}{ Roof } & \multicolumn{2}{c|}{ Exterior walls } & \multicolumn{2}{c|}{ Ventilated floors } \\
\cline { 2 - 7 } & $\mathbf{U}$ & $\mathbf{R t}$ & $\mathbf{U}$ & $\mathbf{R t}$ & $\mathbf{U}$ & $\mathbf{R t}$ \\
\cline { 2 - 7 } & $\mathbf{W} / \mathbf{m}^{2} \mathbf{K}$ & $\mathbf{W} / \mathbf{m}^{2} \mathbf{K}$ & $\mathbf{W} / \mathbf{m}^{2} \mathbf{K}$ & $\mathbf{W} / \mathbf{m}^{2} \mathbf{K}$ & $\mathbf{W} / \mathbf{m}^{2} \mathbf{K}$ & $\mathbf{W} / \mathbf{m}^{2} \mathbf{K}$ \\
\hline 1 & 0.84 & 1.19 & 4.0 & 0.25 & 3.6 & 0.28 \\
\hline 2 & 0.60 & 1.67 & 3.0 & 0.33 & 0.87 & 1.15 \\
\hline 3 & 0.47 & 2.13 & 1.9 & 0.53 & 0.7 & 1.43 \\
\hline 4 & 0.38 & 2.63 & 1.7 & 0.59 & 0.60 & 1.67 \\
\hline 5 & 0.33 & 3.03 & 1.6 & 0.63 & 0.50 & 2.00 \\
\hline 6 & 0.28 & 3.57 & 1.1 & 0.91 & 0.39 & 2.56 \\
\hline 7 & 0.25 & 4.00 & 0.6 & 1.67 & 0.32 & 3.13 \\
\hline
\end{tabular}

It is evident that the final decision accepts the most demanding proposals (in Thermal Zones 1, 6 and 7), which are also sectors with fewer inhabitants and fewer buildings. On the other hand, in Thermal Zones 2, 3, 4 and 5 (which possibly include more than $80 \%$ of the population and construction activity) it takes an intermediate position, closer to Option A.

It is important to note that firstly, any improvement in the insulation conditions of the walls involves not only a technological update of the construction solutions but also implies an extra cost that cannot be passed on to the construction companies and, of course, cannot be passed to the beneficiaries of social housing. Thus, this is not only a technical issue but also an economical one. On the other hand, on the date of the studies, most of the social housing in the central areas of the country (Thermal Zones 2, 3, 4 and 5) were made of ceramic brick masonry. The only industry that could adapt to the increasing demands of thermal insulation without extra insulation was the ceramic brick industry. 
The above point explains the importance of the previously mentioned "Alternatives to Improve the Thermal Characteristics of Ceramic Brick" report. Analysing the alternatives of the industry to improve the thermal conditions of bricks, it concluded that the best option was to slightly modify its dimensions and its internal geometry, increasing the percentage of voids. However, these improvements are conditioned to the modification of the current Chilean structural design regulations, so tests and analyses were made. This finally allowed the ministry to propose the indicated $U$ values, since the $U$ value of $1.9 \mathrm{~W} / \mathrm{m} 2 \mathrm{~K}$ (for thermal zone 3) could be achieved with the new family of bricks. For concrete buildings, these values are not achievable without including additional thermal insulation in the walls. Despite being based on a long study and technical background, the final decision was political. This reduced the financial impact of thermal regulation and allowed the industry to continue operating in social housing buildings with little change in the design and material. Today, statistics show that ceramic brick has lost market share compared to reinforced concrete. This is due to the fact that the buildings in Chile have increased in height and, given the structural restrictions of our regulations, it is almost impossible to achieve structural standards with brick buildings (even with reinforced concrete backing) over three storeys.

As it was a relative new issue for the market, the Chilean Construction Institute published a manual [5] explaining how to deal with the new thermal regulations, including some simple formulae and building solutions for the different thermal zones.

\section{Sustainable building certification}

The presence and increasing importance of LEED certification in Chile in the early years of this century showed that certification was an important tool to ensure compliance with the agreed minimum standards. Along with this, the need for local certification which effectively served the country's diverse climates became evident.

Between 2009 and 2012, the Chilean Construction Institute conducted a study to evaluate the construction design strategies and environmental quality standards and efficient use of energy in public buildings, through monitoring built public buildings. For the Ministry of Public Works with the collaboration of different universities, the IC coordinated and managed the project that lays the foundation for a sustainable building certification system. Subsequently, the construction institute was awarded the study "Design and implementation of the National Certification System for Environmental Quality and Energy Efficiency for Buildings for Public Use" (or CES -its initials in Spanish for sustainable building certification), also with the collaboration of the University of Chile. The Ministry of Public Works, the Chilean Chamber of Construction and the Chilean Architects Association acted as principals of this enterprise. In July 2014, an agreement was signed designating the Chilean Construction Institute as the administrative entity of the sustainable building certification.

The operational model of the certification requires that the certification be carried out by expert advisors accredited to the CES (there are currently 265 accredited advisers) whose report is evaluated by an evaluating entity. The administrative entity has a steering committee representing the associates. Two expert panels support this work: The Advisory Committee (with the participation of institutions) and the Technical Committee (with the participation of the evaluating entities, expert CES advisors and specialists).

The certification model is similar to other certifications in the sense that it provides scores in different areas, setting voluntary and mandatory requirements for different items [6]. Mandatory minimum requirements have been established (14 in the design stage: 6 in 
the architecture category, 8 in the facilities category) plus 1 in management and 1 in construction. From a maximum of 100 points, values from 30 to 54.5 points qualify as “certified building" label, from 55 to 69.5 points as "outstanding certification" label and from 70 to 100 points for the "extra outstanding certification" label. Two main areas were established: architecture (21 items) and facilities (23 items). For each of these, indoor environment quality, energy use, water use and waste are evaluated. Aside from this, three other areas are evaluated: management, construction (in waste management) and operation and maintenance. This allows matching the "Plus" label and demands control, instrumentation and retrofit actions during operation of the building. One of the differentiating aspects of this model is the great emphasis on passive architecture and design and its consideration to the country's climatic conditions in order to determine some of the design requirements. A brief of this is shown below [6].

Table 6. CES point matrix for issues and categories [6].

\begin{tabular}{|c|c|c|c|c|}
\hline \multirow[b]{2}{*}{ Issue } & \multicolumn{2}{|c|}{ Design } & \multirow[b]{2}{*}{$\begin{array}{c}\text { C. } \\
\text { Construction }\end{array}$} & \multirow[b]{2}{*}{$\begin{array}{c}\text { D. } \\
\text { Operation }\end{array}$} \\
\hline & $\begin{array}{c}\text { A. } \\
\text { Architecture }\end{array}$ & $\begin{array}{c}\text { B. } \\
\text { Facilities }\end{array}$ & & \\
\hline $\begin{array}{l}\text { 1. Indoor } \\
\text { environment } \\
\text { quality }\end{array}$ & 36.5 & $9(14)$ & - & - \\
\hline 2. Energy & 25 & 18 & - & - \\
\hline 3. Water & $3(2)$ & $7.5(3.5)$ & - & - \\
\hline 4. Waste & 1 & - & +1 & - \\
\hline 5. Management & "Project integ & ted design" & - & $\begin{array}{l}\text { "Opera- } \\
\text { tional Plus } \\
\text { Label" }\end{array}$ \\
\hline
\end{tabular}

The model has evolved over time, incorporating new types of buildings (hospitals in 2017), updates (2018) and other projects currently under development (such as CES certification for existing buildings, the development of airport certification, the monitoring of existing buildings and the energy rating of public buildings). All these new projects have been made possible thanks to new collaboration agreement partners, such as the Ministry of Energy. To date, 319 buildings have been registered, certified or are in the process of being certified. For local standards, the regional coverage that the certification process has achieved is noteworthy. This contrasts with the strong centralism concentrated in the Santiago Metropolitan Region that is observed in other indicators. The following chart (Figure 7) shows how CES certification has been positioning itself in the local market. However, it is important to note that while LEED certification focuses mainly on private buildings, CES certification currently focuses on public buildings. 


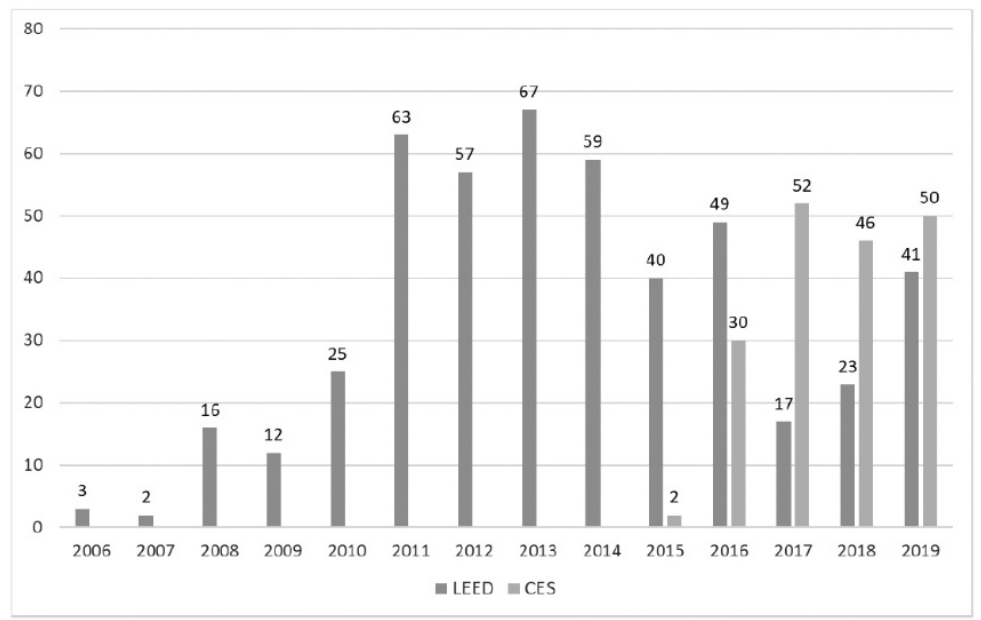

Fig. 1. CES and Leed certificated buildings in Chile 2006 - 2019 [7].

The cost of the certification process does not exceed $0.4 \%$ of the total cost of the project. According to studies, the energy consumption of some certified buildings is very encouraging.

Table 7. CES certificated buildings performances.

\begin{tabular}{|l|l|l|l|l|l|}
\cline { 2 - 6 } \multicolumn{1}{c|}{} & \multicolumn{1}{c|}{ Nombre } & \multicolumn{1}{c|}{ Uso } & \multicolumn{1}{c|}{ Región } & \multicolumn{1}{c|}{ Certificado } & Consumo energía \\
\hline & Sede Osorno CChC & Oficinas & $\begin{array}{l}\text { Osorno } \\
\text { Los Lagos }\end{array}$ & $\begin{array}{l}\text { Certificado } \\
40 \text { puntos } \\
2014\end{array}$ & $\begin{array}{l}30-35 \mathrm{kWh} / \mathrm{m} 2 \text { año } \\
\text { (térmico) }\end{array}$ \\
\hline & $\begin{array}{l}\text { Escuela Manuel } \\
\text { Anabalón }\end{array}$ & Educación & $\begin{array}{l}\text { Panguipulli } \\
\text { Los Ríos }\end{array}$ & $\begin{array}{l}\text { Certificado } \\
50 \text { puntos } \\
2015\end{array}$ & $\begin{array}{l}33-37 \mathrm{kWh} / \mathrm{m} 2 \text { año } \\
\text { (térmico) }\end{array}$ \\
\hline & PDI Puerto Montt & Oficinas & $\begin{array}{l}\text { Puerto Montt } \\
\text { Los Lagos }\end{array}$ & $\begin{array}{l}\text { Certificado } \\
43 \text { puntos } \\
2015\end{array}$ & $\begin{array}{l}17 \mathrm{kWh} / \mathrm{m} 2 \text { año } \\
\text { (eléctrico total) }\end{array}$ \\
\hline
\end{tabular}

\begin{tabular}{|l|l|l|l|l|l|}
\hline & $\begin{array}{l}\text { Biblioteca Regional } \\
\text { Gabriela Mistral }\end{array}$ & $\begin{array}{l}\text { Servicios } \\
\text { (Biblioteca) }\end{array}$ & $\begin{array}{l}\text { La Serena } \\
\text { Coquimbo }\end{array}$ & $\begin{array}{l}\text { Certificado } \\
46 \text { puntos } \\
2017\end{array}$ & $\begin{array}{l}24 \mathrm{kWh} / \mathrm{m} 2 \text { año } \\
\text { (eléctrico total) }\end{array}$ \\
\hline & $\begin{array}{l}\text { Comisaria La } \\
\text { Portada }\end{array}$ & $\begin{array}{l}\text { Servicios } \\
\text { (Seguridad) }\end{array}$ & $\begin{array}{l}\text { Antofagasta } \\
\text { Antofagasta }\end{array}$ & $\begin{array}{l}\text { Certificado } \\
48,5 \text { puntos } \\
2017\end{array}$ & $\begin{array}{l}76 \mathrm{kWh} / \mathrm{m} 2 \text { año } \\
\text { (eléctrico total) }\end{array}$ \\
\hline & $\begin{array}{l}\text { CDI Caldera } \\
\text { E.A. Central }\end{array}$ & $\begin{array}{l}\text { Servicios } \\
\text { (Deporte) }\end{array}$ & $\begin{array}{l}\text { Caldera } \\
\text { Atacama }\end{array}$ & $\begin{array}{l}\text { Destacado } \\
56 \text { puntos } \\
2018\end{array}$ & $\begin{array}{l}20 \mathrm{kWh} / \mathrm{m} 2 \text { año } \\
\text { (eléctrico total) }\end{array}$ \\
\hline
\end{tabular}


On the other hand, considering the savings in terms of energy and $\mathrm{CO} 2$ equivalent, the results also show interesting figures, as expressed in the studied cases.

Table 8. CES certificated buildings performances [7].

\begin{tabular}{|c|c|c|c|}
\hline Project & Region & $\begin{array}{c}\text { Energy consumption } \\
\text { reduction (design) }\end{array}$ & $\begin{array}{c}\text { Emission reduction } \\
\text { (design) }\end{array}$ \\
\hline $\begin{array}{c}\text { Collín Alto } \\
\text { School }\end{array}$ & Vilcún - Araucanía & $\begin{array}{c}52 \% \mathrm{kWh} / \mathrm{m} 2 \text { year } \\
\text { (thermal \& electrical) }\end{array}$ & $\begin{array}{c}69 \% \mathrm{CO} 2 \text { eq. year } \\
\text { (thermal \& electrical) }\end{array}$ \\
\hline $\begin{array}{c}\text { Prosecutor's } \\
\text { Building Pucón }\end{array}$ & Pucón - Araucanía & $\begin{array}{c}41 \% \mathrm{kWh} / \mathrm{m} 2 \text { year } \\
\text { (thermal \& electrical) }\end{array}$ & $\begin{array}{c}38 \% \mathrm{CO} 2 \text { eq. year } \\
\text { (thermal \& electrical) }\end{array}$ \\
\hline
\end{tabular}

The benefits of building sustainability certification are widely known and shared. The difference is how these methodologies are developed and how adequate or remote they are to the local conditions and realities of each country. CES has established a voluntary standard that exceeds the related requirements established by current regulations (OGUC). New initiatives have been added, such as the sustainable housing certification (CVS) promoted by the Ministry of Housing and Urban Planning.

\section{Final comments}

The discussed cases are only part of the work of the Chilean Construction Institute. New tasks, such as the development of a seismic model code for Latin America and the Caribbean, are scheduled. In 2019, an agreement to create a permanent commission of the seismic model code was signed. The objective of this non-governmental organisation is to promote the preparation, review and update the voluntary technical and referential documentation of structural design in the event of earthquakes, hurricanes, tsunamis and other natural phenomena. Public and private organisations from thirteen countries are part of this initiative. The Chilean Construction Institute is appointed as the General Secretariat of the Executive Committee. The first aim is to prepare a seismic hazard map for the region. Developing a sustainable building certification model for Latin America and the Caribbean is being put forward.

Inter sectorial collaboration is an effective formula when competing interests between actors in the construction sector are encountered. Achieving a minimum basic consensus enables the generation of the necessary confidence for future evolution and improvement. Preservation of this horizontal and shared space is also important for the discussion of ideas. This was demonstrated throughout the work of updating the statutes of the construction institute during 2019. Pressure was exerted so that the partners that made the greatest financial contributions to the operation of the IC had greater representativeness and relative weight in the decision making process. This attempt was fortunately blocked. It is important is to preserve this collaboration in which all voices have the same relative importance. The priorities that are set are the result of this democratic procedure and process. As a representative of the University of Chile at the Institute, I cannot but celebrate this republican spirit.

\section{References}

1. Construction Institute of Chile, Proposal 2nd Phase Thermal Regulation for housing and changes in Article 4.1.10 Of. General Urbanism and Construction Regulation, OGUC, (September 2003) 
2. National Institute of Standardization, NCh1079 - Arquitectura y Construcción, Zonificación climático habitacional para Chile y Recomendaciones para el Diseño Arquitectónico, (1977)

3. https://www.ine.cl/estadisticas/economia/edificacion-y-construccion/permisos-deedificacion

4. Ministry of Housing and Urban Planning, Art. 4.1.10, General Urbanism and Construction Regulation, (OGUC), Chile

5. Construction Institute of Chile, Manual de Aplicación Reglamentación Térmica Ordenanaza General de Urbanismo y Construcciones, Santiago de Chile (2006)

6. Construction Institute of Chile, Manaual de Evaluación y Calificación Certificación EDificio Sustentable, Santiago de Chile (2014)

7. CES report to Chilean Construction Institute Boar, (May 2020) 